\title{
Characterization of the Uterus and Mammary Glands of the Female African Giant Rats (Cricetomys gambianus, Waterhouse) in Nigeria
}

\author{
Caracterización del Útero y Glándulas Mamarias de la Rata Africana Gigante Hembra \\ (Cricetomys gambianus, Waterhouse) en Nigeria
}

*Adebayo Koyuum Akinloye \& **Bankole Olusiji Oke

\begin{abstract}
AKINLOYE, A. K. \& OKE, B. O. Characterization of the uterus and mammary glands of the female african giant rats (Cricetomys gambianus, Waterhouse) in Nigeria. Int. J. Morphol., 28(1):93-96, 2010.

SUMMARY: Morphology of the uterus and mammary glands were studied in sexually matured female African giant rat. The uterus was identified as being duplex, having two separate uterine horns and two cervices. The two cervices were partially fused and separated by a mid-saggital septum. Their thick musculatures projected caudally into the vagina as the portio vaginalis uteri. The results also showed that eight mammary glands, distributed along the lateral aspects of thoracic and inguinal regions, were present. The thoracic and the inguinal regions had four mammary glands each and were arranged in two pairs of cranial and caudal rows. These findings fill some gaps created by the dearth of information on the reproductive biology of the female African giant rat.
\end{abstract}

KEY WORDS: ; Cervices duplex; Thoracic and inguinal regions.

\section{INTRODUCTION}

The African giant rat (Cricetomys gambianus Waterhouse) also known as the African Pouch rat, resembles a hamster in having a storage pouch inside of each cheek. The pouch rats are huge and they are among the largest of the murid rodents (Novak \& Paradiso, 1991). Attempts at domestication of the African giant rat have been made (Ajayi, 1977) and still continue. Thus it is necessary that its biology including the biology of reproduction be thoroughly investigated as a means of providing adequate information to aid the process of domestication. Much work has already been done on the reproductive biology of the male African giant rat (Oke, 1985; Oke et al., 1989) while existing reports on the reproductive biology of the female appear to be limited only to cytological and haematological changes in the oestrous cycle (Oke \& Oke, 1999).

The uterus is the major female reproductive organ of most mammals, including humans. One end, the cervix, opens into the vagina; the other is connected on both sides to the fallopian tubes. The main function of the uterus is to accept a fertilized ovum which becomes implanted into the endometrium, and derives nourishment from blood vessels which develop exclusively for this purpose (Fawcett \& Jensh, 2002; Eurell \& Frappier, 2006).

The mammary gland is a modified skin gland connected with a streak canal. The later is lined by stratified squamous epithelium. The mammary tissue itself is divisible into lobes, each of which is composed of many alveoli. The alveolus is the secretory unit of the gland. It is lined by a single layer of cuboidal to columnar epithelial cells and surrounded by branched myoepithelial cells. The myoepithelial cells contract under the influence of oxytocin and cause the discharge of accumulated milk within the alveolus (Hafez, 1970; Wiess, 1983).

The uterus and the mammary glands have been classified in various species of animals (Hafez). However, no literature exists on the type of uterus and mammary glands in the female African giant rat. Therefore, this paper, an aspect

\footnotetext{
* Department of Veterinary Anatomy, University of Agriculture, Abeokuta. Nigeria.

** Department of Veterinary Anatomy, University of Ibadan, Ibadan. Nigeria.
} 
of series of researches aimed at elucidating the reproductive biology of the female African giant rat, characterizes the uterus and the mammary glands for the first time.

\section{MATERIAL AND METHOD}

Ten sexually matured female African giant rats were used for the morphological studies of the uterus and mammary glands. All the animals were captured alive in Ibadan, Oyo state, Nigeria. All the animals were housed singly in cages in the Giant Rat Colony of the Experimental Animal unit of the Faculty of Veterinary Medicine, University of Ibadan, Ibadan and were allowed to acclimatize before exsanguinations.

The animals were fed on a diet of mouse cubes $(21 \%$ protein, $3.5 \%$ fat, $6 \%$ fibres, $0.8 \%$ calcium, $0.8 \%$ phosphorous) from Ladokun Feeds Nigeria Limited, Ibadan, Nigeria. Supplements of palm kernel fruits, pawpaw, yam and cassava tubers as well as fresh and partially dry maize were given. Water was provided ad libitum.

Inhalation anesthesia was achieved using ether before exsanguinations. The animals were placed on dorsal recumbency and the ventral aspects were observed for number, location and distribution of mammary glands. Thereafter, a mid-line abdominal incision was made craniocaudally from the xiphoid cartilage to the pubic symphysis in order to expose the structures in the peritoneal cavity. After partial removal of the skin covering the thigh, the inner thigh muscles were severed on both sides of the pelvic arch. The pubic symphysis was disarticulated or cut through with bone shears and pulled apart by lateral traction on either side. The reproductive organ was exposed and the uterus was observed in situ and later dissected out. The organs were temporarily stored in covered Petri-dishes kept moist by filter paper soaked in physiological saline solution.

\section{RESULTS}

Uterus. A duplex uterus was observed in the female giant rat. There were two separate uterine horns, a partial fusion of the two horns caudally, the body and two cervices (Figs. 1 and 2). When the animal is on dorsal recumbency, the uterus lies directly on the colon but ventral when it is on standing position. While the uterus lies almost entirely within the abdominal cavity, its cervix uteri extend into the peritoneal portion of the pelvic cavity. The uterus is suspended by the mesometrium that originated from the dorsolateral pelvic wall and the lumber region. The mesometrium contains smooth musculature, which is continuous with the longitudinal muscle layer of the uterus.

Mammary Glands. Eight mammary glands that were distributed along the lateral aspects of the thoracic and the inguinal regions were identified in the female African giant rat. Four mammary glands are located in the thoracic region while the other four are in the inguinal region. In both regions, the mammary glands are arranged in two pairs of cranial and caudal rows. In the thoracic region the mammary glands in the cranial row are located midway between the upper limbs when the elbows rest on the body while the two glands in the caudal row are located just at the tip of the elbow (Fig. 3). In the inguinal region, the glands in the two rows lie between the iliac crest and the ischial tuberosity (Fig. 4).

\section{DISCUSSION}

Four main types of uteri have been reported to occur among the different mammalian orders based largely on differences in the prominence of their two parts, the body and the two horns. These are: bipartite, as in cows; bicornuate, as in pigs; simplex, as with the pear-shaped one found in humans and horses; duplex, found in rabbits, guinea pigs, mice and rats (Hafez). Results from the present study characterized the uterus of the African giant rat as a duplex uterus. There are two separate uterine horns and two cervices. The two uterine horns share a common outer longitudinal layer of myometrium leading to a partial fusion caudally. The two partially fused cervices were separated by a mid-saggital septum and their thick musculatures project caudally into the vagina as the portio vaginalis uteri. These gross features are generally similar to those reported for laboratory rats, mice, rabbits and guinea pigs (Hafez; Hebel \& Stromberg, 1976; Fawcett \& Jensh).

The mammary glands of the female African giant rat are being characterized for the first time in this study. Results showed that 8 mammary glands, distributed along the lateral aspects of thoracic and inguinal regions are present. The thoracic and the inguinal regions have 4 mammary glands each and are arranged in 2 pairs of cranial and caudal rows. The number, distribution, and arrangement of mammary glands in the giant rat are at variance with all other species of laboratory animals. In the rat, for example, there are 12 mammary glands arranged in two ventrolateral series along thoracic and inguinal regions while there are 10 mammary glands in the mouse arranged in 6 thoracic and 4 abdominoinguinal. In guinea pig, there are 2 mammary glands located 


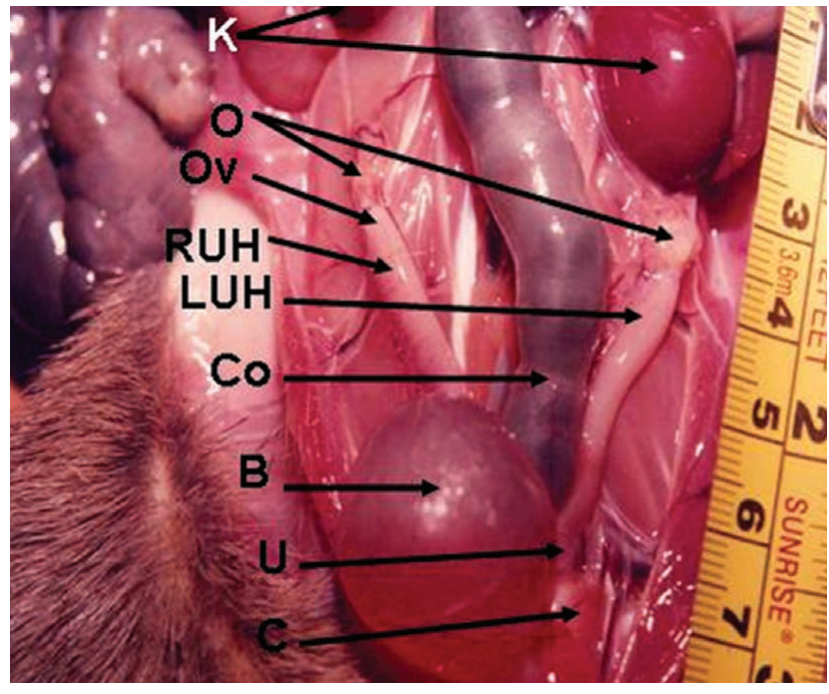

Fig. 1. The reproductive organ of the adult female giant rat in situ. Observe the relationship of the ovaries $(\mathrm{O})$ to the kidneys $(\mathrm{K})$. Note that uterus $(\mathrm{U})$ lies on the colon $(\mathrm{Co})$ and both right uterine horn (RUH) and left uterine horn (LUH) run parallel to the colon then diverge laterally. The cervix $(\mathrm{C})$ is short and the oviduct $(\mathrm{Ov})$ is barely visible. The urinary bladder (B) is related to the cranial end of the vagina.

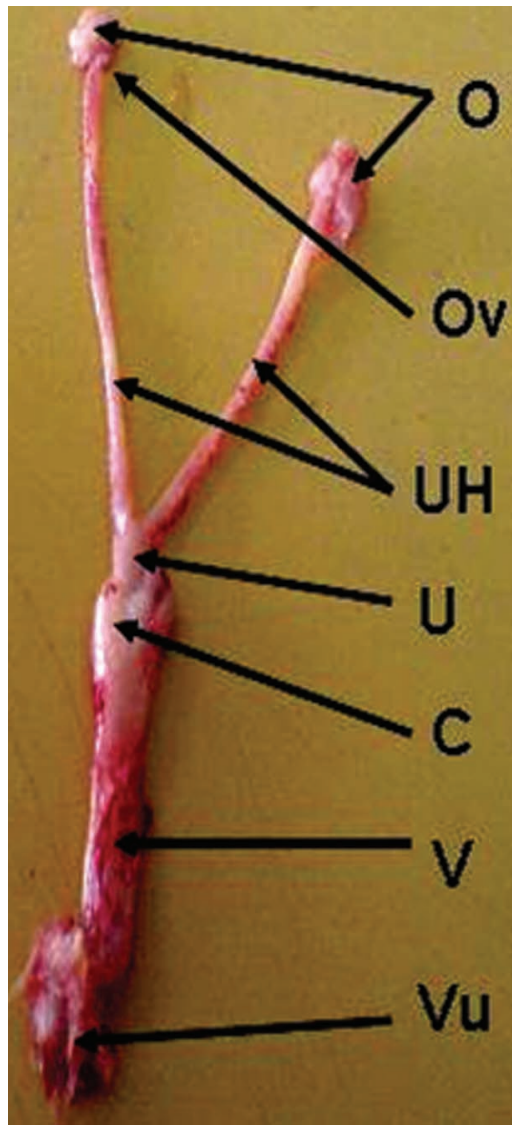

Fig. 2. The dorsal view of the female reproductive tract of the adult African giant rat showing various segments of the organ. Observe a pair of ovaries $(\mathrm{O})$ stalked on the uterine horns (UH) by short Oviducts (Ov). Note the short body of uterus (U), distinct Cervix (C), Vagina (V) and Vul$\mathrm{va}(\mathrm{Vu})$.

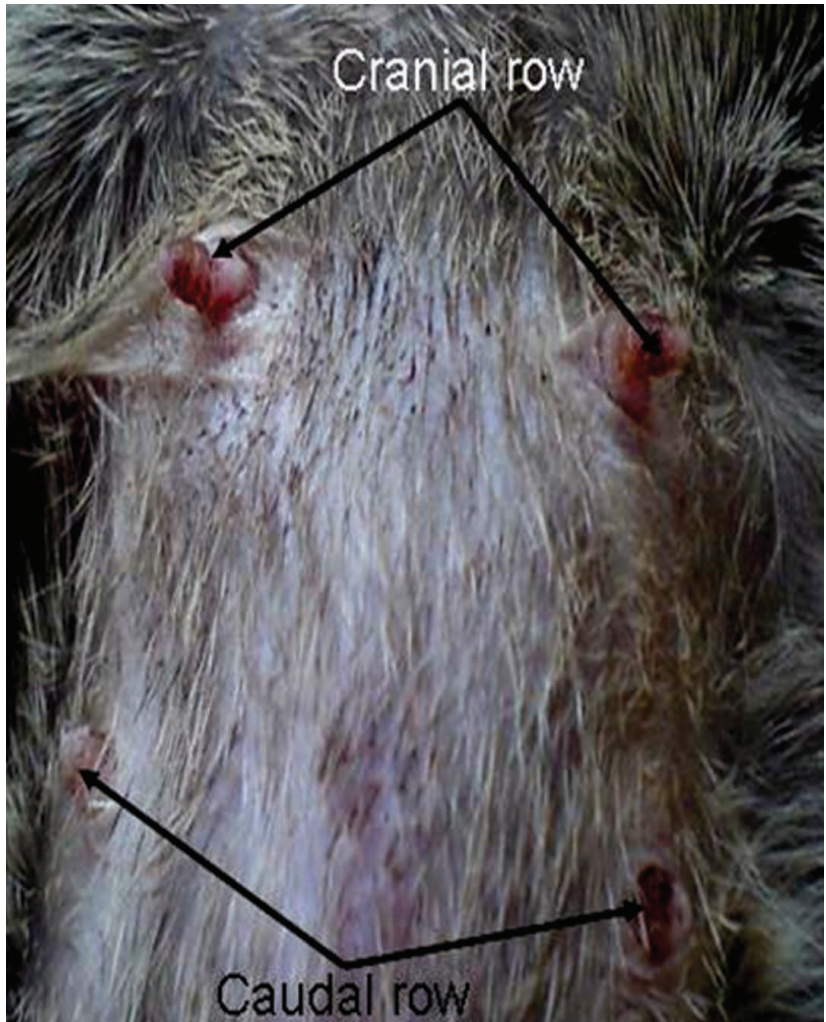

Fig. 3. Mammary glands in the thoracic region. Note the four teats of the mammary glands that are arranged in pairs of cranial row and caudal row.

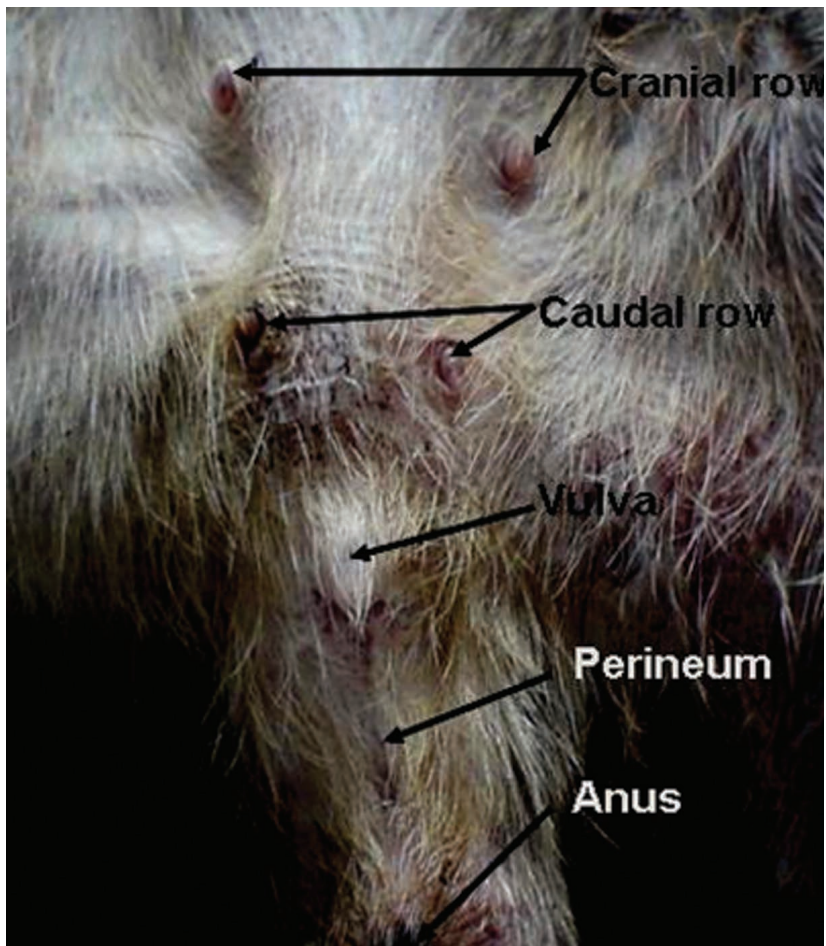

Fig. 4. Mammary glands in the inguinal region. Observe the four teats in two pairs of cranial and caudal rows. Also note the bulged vulva as it relates to the anus 
in the inguinal region while the 8 mammary glands present in the rabbit are in 2 ventrolateral series along thoracic and abdomino-inguinal regions (Hafez). This study provides baseline information on the uterus and the mammary of the female African giant rat that could be useful in future laboratory investigations. However, further series of researches aimed at characterizing the uterus of the female African giant rat histologically and ultrastructurally at different stages of the oestrous cycle are on-going in order to elucidate the reproductive biology.

AKINLOYE, A. K. \& OKE, B. O. Caracterización del útero y glándulas mamarias de la rata Africana gigante hembra (Cricetomys gambianus, Waterhouse) en Nigeria. Int. J. Morphol., 28(1):93-96, 2010.

RESUMEN: La morfología del útero y las glándulas mamarias fueron estudiadas en ratas Africanas gigantes sexualmente maduras. El útero fue identificado como doble, teniendo dos cuernos uterinos separados y dos cervix. Los dos cervix estaban parcialmente fusionados y separados por un tabique mediano sagital. Su grosor muscular se proyecta caudalmente en la vagina como la porción vaginal del cuello uterino. Los resultados también mostraron que ocho glándulas mamarias, distribuidas a lo largo de las zonas laterales de tórax y la región inguinal estaban presentes. La región torácica e inguinal tenía cuatro glándulas mamarias en cada lado y se organizaron en dos pares de filas craneales y caudales. Estos hallazgos completan algunas lagunas creadas por la escasez de información sobre la biología reproductiva de la rata gigante Africana hembra.

PALABRAS CLAVE: Útero doble; Regiones torácica e inguinal.

\section{REFERENCES}

Ajayi, S. S. Field observation on the African giant rat Cricetomys gambianus Waterhouse in southern Nigeria. E. Afr. Wildl. J., 151:191-8, 1977.

Eurell J. A. \& Frappier B. L. Female Reproductive System. In: Dellmann's Textbook of Veterinary Histology. 6th Ed. Ames, Iowa, USA, Blackwell Publishing, 2006. pp.256-78.

Fawcett, D. W. \& Jensh, R. P. Female Reproductive System. In: Bloom \& Fawcett's Concise Histology. $2^{\text {nd }}$ Ed. London, Arnold Publishers. 2002. pp.283-96.

Hafez, E. S. E. Reproduction and breeding techniques for laboratory animals. Philadelphia, USA, Lea \& Febiger, 1970.

Hebel, R. \& Stromberg, M. W. Female Reproductive Organs. In: Anatomy of the Laboratory Rat., Baltimore, U.S.A., The Willian \& Wilkin Company, 1976. pp.76-82.

Novak, R. M. \& Paradiso, J. L. Walkers Mammals of the World, Vol II. The Johns Hopkins University Press, Baltimore.http://www.altpet.net/rodents/cricetomys/ gprat2.html, 1991.

Oke, B. O. The effect of season on the reproductive organs of the male African giant rat (Cricetomys gambianus, Waterhouse) in Ibadan, Nigeria. Afr. J. Ecol., 23(1):67$70,1985$.
Oke, B. O.; Aire, T. A.; Adeyemo, O. \& Health, E. The ultrastructure of the epididymis of the African giant rat (Cricetomys gambianus, Waterhouse). J. Anat., 164:7589, 1989.

Oke, O. A. \& Oke, B. O. Vaginal cytological changes during the oestrous cycle of the adult female African giant ( $C$. gambianus, Waterhouse). Trop. Vet., 17:169-80, 1999.

Weiss, L. The female reproductive system. In: Histology, Cell and Tissue Biology. $5^{\text {th }}$ Ed. New York, Elsevier Science Publishing Co. Inc., 1983. pp.914-43.

\author{
Correspondence to: \\ Dr. A. K. Akinloye \\ Department of Veterinary Anatomy, \\ University of Agriculture \\ PMB 2240 \\ Abeokuta, \\ NIGERIA
}

Telephone: +2348035838735

Email: bayoakinloye@gmail.com

Received: 08-10-2008

Accepted: 04-11-2009 